\title{
Symbolism in Winesburg, Ohio
}

\author{
Yang Zhao \\ Foreign Languages College, Beihua University, Jilin 132013, China.
}

Keywords: Sherwood Anderson, Winesburg, Ohio, Grotesque.

\begin{abstract}
Sherwood Anderson is a special literary figure in American literature. His works, especially his short stories, have attracted generations of readers. Winesburg, Ohio is one of well-known works of Sherwood Anderson. It uses symbolism many times to write the industrialized and mechanical civilization, which gradually become dominated all social forces and period changes. In this situation people's spiritual, moral change and performance curb the trend of industrial society split by the self and the distortion of human nature, and suffer setbacks instinct, exposing the industrial civilization of the human devastation in capitalist society.
\end{abstract}

\section{Introduction}

Anderson is primarily remembered as the author of Winesburg, Ohio. The book provides the solid foundation of his literary reputation. Some critics misinterpreted it in terms of realism or naturalism, which places high value on external appearance rather than the inner essence of life. Anderson. Conversely, values the essence of things, considering physical things meaningless. The characters' emotions and life's meaning and purpose are conveyed through the concrete images, or the few words, or a single gesture. For Anderson, the physical thing is more than what it is in reality. It has many associations. It is doubtless that the book is made significant by its symbolism. This paper discusses Anderson's art of symbolism by exploring the major symbols in Winesburg, Ohio. From this, it is clear that achievements of Sherwood Anderson owe much to the use of symbolism.

\section{The traditional symbol}

According to the different sources of symbols, the symbols in Winewburg, Ohio can be generally classified into traditional symbol and private symbol. Traditional symbol is defined by social custom or cultural tradition, which is well known to readers. It stems from experience of mankind, or from a literary allusion, or from associations with common sense. For a long time, a certain cultural background is established in literature.

In Winesburg, Ohio, the most significant traditional symbol is darkness. The repeated element is involved in a very majority of the stories. In "Hands", "Mother", and "Loneliness", for example, the light is that of a single lamp; in "The Untold Lie" the concluding scene is faintly lit by the last twilight; in "Sophistication" Garage Willard and Helen Whit look at each other "in the dim light" afforded by "the lights of the town reflected against the sky", though at the other end of the fair grounds a few race track men have built a fire that provides a dot of illumination in the darkness. Finally, many of the tales end with the characters in total darkness. The symbol of darkness sets the fundamental tone for the book which is about the "night world" of human personality.

Darkness suggests the darkness and deepest part in man's mind. It symbolizes the loss of man's soul. The grotesques' eccentric behaviors or the burst of their repressed drives mostly take place in the night or dusk. Thus Anderson adopted “darkness" to better reveal the characters' inner world, their thwarted emotions and repressed drives. The dim light functions only as the brief glimpse into an individual soul.

\section{The private symbols}

Moving from the traditional symbol, we find that the use of private symbols is one of the most 
striking elements in the work. Private symbol is created by the writer, bearing the unique implication. The private symbols in Winesburg, Ohio can be discussed at the following levels: character as symbol, action as symbol, object as symbol.

"Grotesque" is a dominant symbol, running through the whole book. The use of the word grotesque sets the motif of the book. In the story we are told that the grotesques live in Ohio which has been quickly industrialized in the late 19th century. Industrialism elevates the standard of living, but it also removes a certain sincerity and integrity from life. The good values of agrarianism have become false ideas, false dreams, and false hopes in a confused society. The individuals, who cling to the "truth" are cut off from the world that has been spoiled by modern industrialism. These people long for love and understanding, search or touch with their fellows, but find no way to contact. To their life becomes frustrated, futile, meaningless, and hopeless. Their striving for the meaning of machine and the confines of convention twist these people into spiritual grotesques. These grotesques mark the mind of Americans in that particular phase of history. However, the connotation of the word grotesque is more than this. Grotesques are, as Anderson points out, like the twisted apples that are left behind in the orchards because they are imperfect. These apples are the sweetest of all, even because of the imperfections that have caused them to be rejected. Thus the nature of the grotesques can be compared to their intrinsic worth that human beings usually ignore.

The paper pill in the story "Paper Pills" is a dominant symbol. Paper pill is the symbol of human isolation. The hero in the story, Doctor Reefy, has a habit of writing his thoughts on bits of paper and putting the bits into his pockets, where they will be twisted into hard little balls. Then he throws them away them away, and begins other scrapes. Then he throws them away, and begins other scrapes. The thoughts written on the paper are never shown to others. The scraps in the pockets become a hard ball after Doctor Reefy has read them and stuffed them away in his pockets. In effect, the hard shells of the pills represent the barriers of isolation that surround human minds, and Doctor Reedy, voluntarily isolates himself rather than tries to overcome those barriers, deliberately avoids inevitable misunderstanding. For Reefy paper pills are the only means of conveying his thoughts in the form of paper pill, rather than communicate with other for fear of being misinterpreted. Nobody can appreciate these beautiful thoughts except his wife. After his wife dies, he loses the way to communicate, and becomes a grotesque. His shortcoming lies not in the thought but in the process of communication, which is the very problem that Anderson tries to solve in his writings. Anderson believes that love and understanding the only solution to the problem of human isolation.

House is also an important symbol in this story. In this story houses imply isolate and durance. Curtis Hartman has him sit in the clock tower. Kate Swift made himself stay at home lonely, Reefy was in his office by himself. The entire house reflects the people who in the city are abnormality. And all the things made the atmosphere consternation.

Anderson is very qualified in employing the technique of symbolism which is loaded with in his most stories. There are many variants in using the techniques of symbolism. The most essential one is to build the symbolic image to convey the intention and felling. In Winesburg Ohio the whole novel of Winesburg Ohio the image of "grotesques" is just such a leading image. It penetrates the entire book. The grotesque feel lost when they are facing the downtrodden and barren life of the mid-west, the aggression of the industrialization coming outside. They are grotesque from appearance and painful in heart. They have fierce pursuit towards life, longing for the emancipation of individuality, love and normal lovemaking. They are oppressed by both the tradition and the new industrialization. This group of grotesque is the accurate portrait of the life and consciousness of the stragglers in the rising period of American capitalism. They are also the epitome of the miserable and painful experience that they cannot avoid when facing the similar problems. It is from the angle of the significance of oneness of the grotesque images that we may say this collection of short stories is a novel with unifying image.

Besides "hand", "room” and "loneliness" are both such images unifying the whole stories. In essence Wing buddle bum's concealing his hands in kids' pockets is symbolic of his attempt to hide a tragic event and put away his past. 


\section{Conclusion}

As is stated above, the use of symbolism contributes to the revelation of the themes and characters' emotions. It is far more effective and vivid than abstract narratives in words. All the problems of the grotesques as well revealed in the moment through a single action, or a single object and so on. The unnamable or vague desires in grotesques' hearts are clarified before readers. In addition, the author's reflections on love and modern industry are conveyed by them. Doubtlessly, the fact that Winesburg, Ohio becomes one of Anderson's master pieces has a close connection with his use of symbolism in the work

Symbolism plays a very important role in American literature. The author wants to say something but by the other, for example in Anderson's Winesburg, Ohio, we discover the house the people the background and the other things also play a special role. Just as characterization and dialogue and plot work on the surface to move the story along, symbolism works under the surface to tie the story's external action to the theme. Early in the development of the fictional narrative, symbolism was often produced through allegory, giving the literal event and its allegorical counterpart a one-to-one correspondence. Allegory is undoubtedly the simplest way of fleshing out a theme, but it is also the least emotionally satisfying because it makes things a little too easy on the reader. We feel that we are being lectured to; it's almost as if the author is stopping every sentence or two to say, "Now pay special attention to this, because if you don't remember it, you won't get the point." Symbolism was often produced through allegory, giving the literal event and its allegorical counterpart a one-to-one correspondence. Symbolism, therefore, is an integral component of fiction, because it enriches the narrative by pulling its message down to the level of our unconscious and anchoring it there.

\section{References}

[1] Anderson, David D, ed .Critical Essays on Sherwood Anderson. Boston: G. K. Hall, 1981.

[2] Gregory, Horace, ed. The Portable Sherwood Anderson. New York: Viking Press, 1977.

[3] Rubinstein, Annette T.. American Literature Root and Flower [M]. Beijing: Foreign Language Teaching and Research Press, 1998. 